\title{
Crystal structure of the ribosomal protein S6 from Thermus thermophilus
}

\author{
M.Lindahl', L.A.Svensson ${ }^{1}$, A.Liljas ${ }^{1,5}$, \\ S.E.Sedelnikova², I.A.Eliseikina², \\ N.P.Fomenkova ${ }^{2}$, N.Nevskaya2 ${ }^{2}$ S.V.Nikonov', \\ M.B.Garber ${ }^{2}$, T.A.Muranova ${ }^{3}$, A.I.Rykonova ${ }^{3}$ \\ and R.Amons ${ }^{4}$
}

\author{
${ }^{1}$ Molecular Biophysics, Chemical Center, University of Lund, Sweden, \\ ${ }^{2}$ Institute of Protein Research, Russian Academy of Sciences, \\ 142292 Pushchino, Moscow Region and ${ }^{3}$ Branch of Shemyakin \\ Institute of Bioorganic Chemistry, Russian Academy of Sciences, \\ 142292 Pushchino, Moscow Region, Russia and ${ }^{4}$ Department of \\ Medical Biochemistry, University of Leiden, PO Box 9503, \\ 2300 RA Leiden, The Netherlands \\ ${ }^{5}$ Corresponding author \\ Communicated by C.G.Kurland
}

The amino acid sequence and crystal structure of the ribosomal protein $\mathbf{S 6}$ from the small ribosomal subunit of Thermus thermophilus have been determined. S6 is a small protein with 101 amino acid residues. The 3D structure, which was determined to $2.0 \AA$ resolution, consists of a four-stranded anti-parallel $\beta$-sheet with two $\alpha$-helices packed on one side. Similar folding patterns have been observed for other ribosomal proteins and may suggest an original RNA-interacting motif. Related topologies are also found in several other nucleic acidinteracting proteins and based on the assumption that the structure of the ribosome was established early in the molecular evolution, the possibility that an ancestral RNAinteracting motif in ribosomal proteins is the evolutionary origin for the nucleic acid-interacting domain in large classes of ribonucleic acid binding proteins should be considered.

Key words: amino acid sequence/ribosomal proteins/RNA interaction/X-ray crystallography

\section{Introduction}

Ribosomes are the ribonucleoprotein organelles on which the mRNA-directed synthesis of proteins takes place. They consist of a large and a small subunit which assemble during the initial stages of protein synthesis. Procaryotic ribosomes comprise three molecules of RNA and $>50$ protein molecules (Wittman, 1982). Ribosomal RNA from a large number of sources have been sequenced (Gutell, 1993). As for the proteins, all of the Escherichia coli proteins have been isolated and sequenced (Wittman, 1982). The structures of six ribosomal proteins from various sources have been solved, namely a C-terminal fragment of $\mathrm{L} 7 / \mathrm{L} 12$ (Leijonmarck et al., 1980), L30 (Wilson et al., 1986), S5 (Ramakrishnan and White, 1992), L6 (Golden et al., 1993), L9 (Hoffman et al., 1994) and S17 (S.W.White, personal communication). The latter is an NMR structure, while the former five were determined by X-ray crystallography. Most ribosomal proteins are relatively small $(<150$ amino acid residues) basic molecules which interact with ribosomal RNA.

Almost all biochemical characterization of S6 stems from E.coli (ES6) which is situated on the platform of the small ribosomal subunit facing the large subunit (Kahan et al., 1981; Stöffler and Stöffler-Meilicke, 1984; Capel et al., 1987). ES6 undergoes an unusual post-translational modification as two to six glutamic acids are added at the C-terminus (Hitz et al., 1975; Schnier et al., 1986). It thereby acquires a variable length of $131-135$ amino acid residues and is the most acidic protein in the small ribosomal subunit ( $\mathrm{pI}=4.8$; Kaltschmidt and Wittman, 1970). The

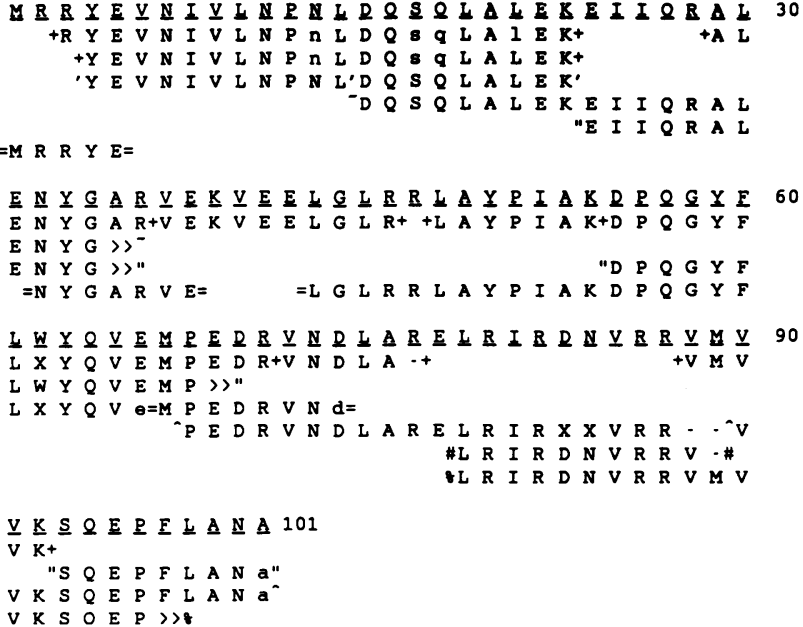

Fig. 1. The primary structure of ribosomal protein S6 from T.thermophilus. $(++)$, tryptic peptides; $(==)$, endoproteinase Glu-C peptides; (" "), endoproteinase Lys-C peptides; (' '), endoproteinase Asp- $\mathrm{N}$ peptides from tryptic peptide; $\left(\hat{\circ}^{\cdots} \cdot{ }^{\cdots}\right), \mathrm{BrCN}$ peptides; $(\# \#)$, endoproteinase Glu-C peptide from $\mathrm{BrCN}$ peptide; $(\sim \sim)$, endoproteinase Asp- $\mathrm{N}$ peptide from $\mathrm{BrCN}$ peptide; (\% \%), endoproteinase Glu-C peptide from endoproteinase Lys-C peptide; $>>$ indicates that the sequencer run was interrupted. Lower case letters indicate an uncertain residue; - indicates that the corresponding residue was not determined in that particular peptide.

$\begin{array}{llll}0 & 20 & 30 & 40\end{array}$

EC MRHYEIVFMVHPD-QSEQVPGMIERYTAAITGAEGKIHRLEDWGRRQLAY It MRRYEVNIVLNPNLDQSQLALEKEIIQRALENYGARVEKVEELGLRRLAY

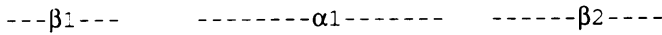

$50 \quad 70 \quad 80 \quad 90 \quad 100$

EC PINKLHKAHYVLMNVEAPQEVTDELETTFRFNDAVIRSMVMRTKHAVTEA

It PIAKDPQGYFLWYQVEMPEDRVNDLARELRIRDNVRRVMVVKSQEPFLAN

$$
\text { --- } \beta 3---\quad--\alpha 2----\beta 4---
$$

$110 \quad 120 \quad 130$

EC SPMVKAKDERRERRDDFANETADDAEAGDSEEEEEE

It $\mathrm{A}$

Fig. 2. Comparison of the primary structure of T.thermophilus S6 with that of E.coli S6. A gap has been introduced to maximize homology. The comparison was based on the table in Gribskov and Burgess (1986). The elements of secondary structure are indicated. 


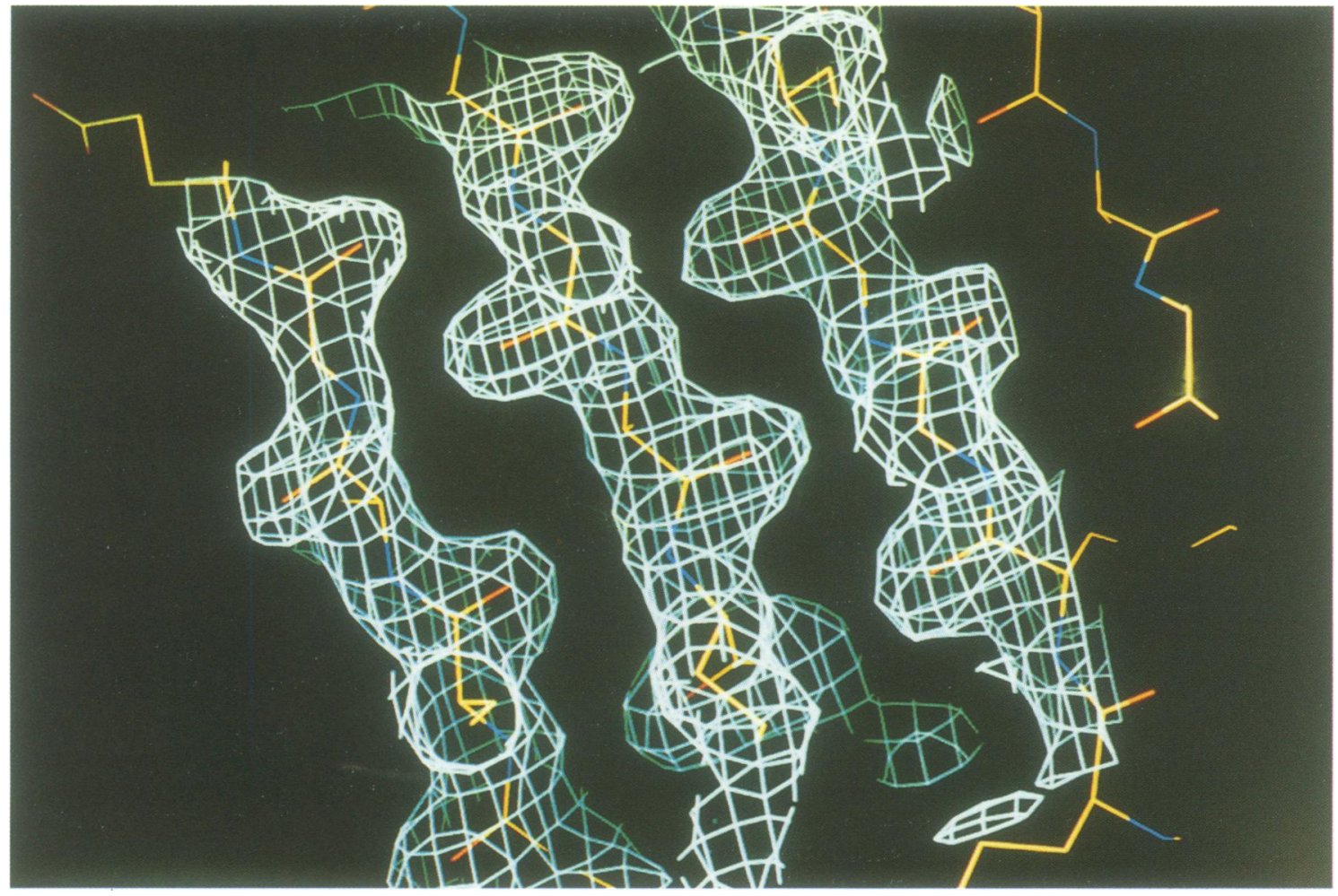

Fig. 3. Strands 2,3 and 1 of the $\beta$-sheet's solvent flattened MIR electron density with polyalanine built into it. The carbonyl oxygens are readily observed.

sequence of S6 from Thermus thermophilus presented in this study consists of only 101 amino acid residues and lacks the trailing glutamic acids whereby it becomes almost neutral, $\mathrm{pI}=6.6$.

Even though ES6 alone cannot bind to the 16S RNA, S6 and $\mathrm{S} 18$ in E.coli form a complex protecting a portion of the 16S RNA (Held et al., 1974; Prakash and Aune, 1978). S6 from T.thermophilus displays unspecific RNA affinity (S.E.Sedelnikova, unpublished data). S6 might, as a part of the complex with $S 18$, have a specific interaction with the 16S RNA. It has been expected that ribosomal proteins have a common origin, but sequence alignment studies have given poor support for this hypothesis (Jue et al., 1980; WittmanLiebold et al., 1984). However, the similarity in tertiary structure between L30 and the C-terminus of L7/L12 has been pointed out as support for this proposal (Leijonmarck et al., 1988). In the present article, the structure of S6 from T.thermophilus is described and found to be similar to several other ribosomal and nucleic acid binding proteins, lending further support for this hypothesis.

\section{Results and discussion}

\section{Primary structure}

The primary structure determination of protein S6 from T.thermophilus is depicted in Figure 1. It has 101 amino acid residues and a calculated molecular weight of 11973 . The $\mathrm{N}$-terminus is not blocked. Since the C-terminal Ala could hardly be seen with Edman sequencing, an independent confirmation was necessary. To that end, the C-terminal $\mathrm{BrCN}$-generated peptide was analyzed also by plasma desorption mass spectrometry. A mass of 1304.1 $\left(\mathrm{MH}^{+}\right)$ was found, corresponding to the predicted mass of
VVKSQEPFLANA (1302.5). The protein lacks Cys, His and Thr, whereas the four amino acids Arg, Glu, Leu and Val together constitute nearly half of the polypeptide chain. A comparison with protein S6 from E.coli reveals only a weak, but nevertheless clear, homology with $27 \%$ sequence identity (Figure 2). The E.coli gene sequence has 30 residues at the C-terminus which are lacking in T.thermophilus. Furthermore, TS6 does not contain the stretch of posttranslationally added glutamic acid residues in the Cterminal.

\section{Electron density map and quality of the model}

The structure was solved by multiple isomorphous replacement (MIR). The initial MIR map was of high quality (Figure 3) and the polypeptide chain was readily traced through the electron density map except for the four Cterminal residues. The refined structure has a crystallographic $R$-factor of $18.3 \%$ and shows good stereochemistry (see Materials and methods).

\section{Overall structure}

The molecule consists of a single domain with an anti-parallel $\beta$-sheet with two $\alpha$-helices packed on one side, leaving the opposite side of the sheet exposed. The connectivity scheme is $\beta 1-\alpha 1-\beta 2-\beta 3-\alpha 2-\beta 4$. The folding pattern gives the molecule a pseudo 2 -fold axis between the central $\beta$-strands perpendicular to the $\beta$-sheet which superimposes the secondary structure elements. The most conserved region between the E.coli and T.thermophilus proteins (residues $48-54$ ) occurs in the extended loop region between $\beta$ strands 2 and 3 forming a 'hook' which partly folds over the $\beta$-sheet, thereby giving it a concave nature (Figure 4). 

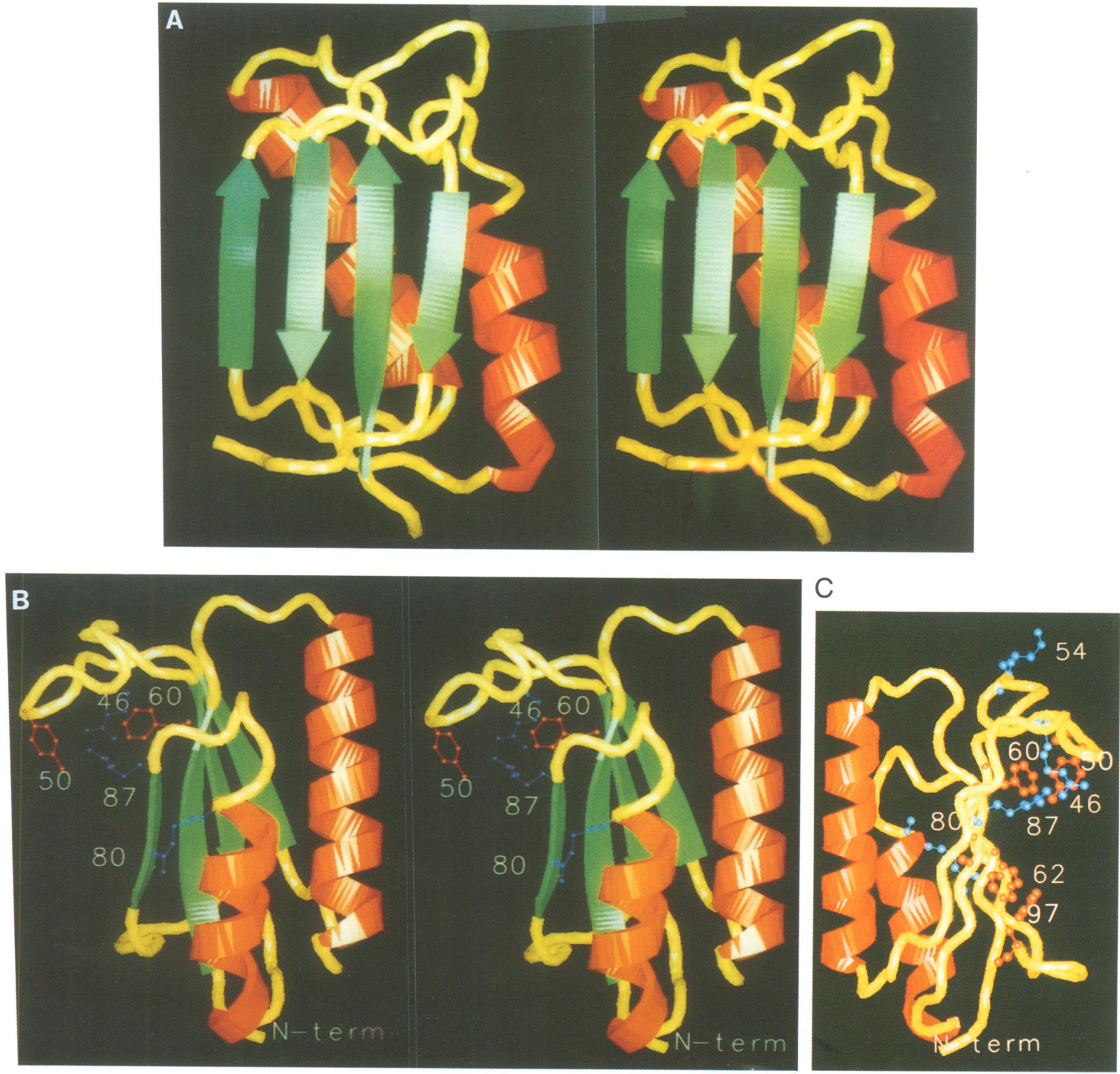

Fig. 4. (A) Stereo picture showing the S6 structure in ribbon style. The N-terminus is to the lower right. (B) Stereo picture showing the concave surface to the left with the residues Arg46, Tyr50, Phe60, Arg80 and Arg87 displayed. These are the conserved residues suggested to participate in RNA interaction. (C) The concave surface with aromatic and basic residues Arg46, Tyr50, Lys54, Phe60, Trp62, Arg80, Arg87 and Phe97.

The C-terminal tail lies over the opposite edge of the $\beta$-sheet and further accentuates the concave surface.

The inner $\beta$-strands $(\beta 1$ and $\beta 3)$ are mainly hydrophobic while the rest of the molecule possesses a large number of charged and polar residues. Interesting features of the S6 structure are the highly exposed, partly conserved aromatic residues Phe60 and Trp62 on $\beta 3$, as well as Tyr50 in the extended loop bridging $\beta 2$ and $\beta 3$. Together with the basic residues Lys54, Arg80 and Arg87 (Figure 4C), they could form a binding site for rRNA explaining the rRNA protection mentioned above.

Folding patterns similar to S6 have been observed in other ribosomal proteins [L7/L12 (Leijonmarck et al., 1980), L30 (Wilson et al., 1986), and L6 and L9 (Golden et al., 1993; Hoffman et al., 1994)]. As seen in Figure 5, L30 forms a basic fold from which all the other proteins can be obtained by insertion or substitution of secondary structure elements. The S6 folding scheme is identical to the topologies of, among other proteins, the RNA binding domain of the U1A snRNP protein (Nagai et al., 1990; Hoffman et al., 1991) and the C-terminal domain of the E2 protein from papilloma virus (Hegde et al., 1992) which binds DNA as well as the enzyme acyl phosphatase (Pastore et al., 1992), ferredoxin (Adman et al., 1973) and mer P, a mercury binding protein in the mercury reductase pathway (P.-O.Eriksson, personal communication). An analysis of $\alpha-\beta$ sandwiches is presented in Orengo and Thornton (1993). U1A binds to RNA by two regions, RNP1 and RNP2, (Jessen et al., 1991) which are highly conserved in more than 20 RNA binding proteins (Mattaj, 1989). These regions map to the two central 
$\beta$-strands and the loop between them, and include three exposed aromatic residues similar to that found for S6 (which, however, does not have the RNP conserved sequences). As S6 does not possess a hydrophobic surface suitable for protein-protein interaction and the concave surface of the $\beta$-sheet is involved in RNA interaction in other RNA binding proteins, the complex between $\mathrm{S} 6$ and $\mathrm{S} 18$ is more likely to be formed by elongation of the $\beta$-sheet on the $\beta 2$ side, as observed for several similar proteins (Gonaux et al., 1990; Nagai et al., 1990; Dumas et al., 1992). E2 forms a barrel-like dimer where the $\beta$-sheets face the inside of the barrel and the $\alpha$-helices on the outside bind to the DNA. In S6 the helix residues are poorly conserved and no obvious potential rRNA interaction area is detected among them. Therefore we suggest this binding mode to be a less likely explanation for the possible rRNA interaction of S6.

The observed folding pattern is also similar to the fold of the palm domains (Figure 5) of p66 pol from HIV-1 reverse transcriptase (Kohlstaedt et al., 1992) and the Klenow fragment from Pol 1 (Ollis et al., 1985). For both these cases, residues important for the catalytic activity map to the loop region connecting the two central $\beta$-strands, as discussed above.

Given the wide distribution of the RNP1 and RNP2 signature sequences in RNA-interacting proteins and the structural similarities between DNA and RNA polymerases (Sousa et al., 1993), it is likely that the described folding pattern is common among DNA and RNA binding proteins. As many ribosomal proteins involved in RNA interactions share a related folding motif, the possibility of an ancestral ribosomal protein as a common origin cannot be excluded.

\section{Materials and methods}

\section{Preparation of T.thermophilus S6}

Thermus thermophilus (strain VK-1) cells were grown according to Gogia et al. (1986). Ribosome isolation was performed as described previously (Gogia et al., 1986). The ribosomal subunits were separated by hydrophobic interaction chromatography and subsequently purified by centrifugation through a $30 \%(\mathrm{w} / \mathrm{v})$ sucrose solution containing $1 \mathrm{M} \mathrm{NH}_{4} \mathrm{Cl}, 50 \mathrm{mM}$ Tris- $\mathrm{HCl}\left(\mathrm{pH} 7.5\right.$ at $20^{\circ} \mathrm{C}$ ), $50 \mathrm{mM} \mathrm{MgCl}_{2}, 2 \mathrm{mM} \mathrm{Na} \mathrm{EDTA}_{2}$ and $1 \mathrm{mM}$ dithiothreitol for $10 \mathrm{~h}$ at $45000 \mathrm{rev} / \mathrm{min}$ in a $50.2 \mathrm{Ti}$ rotor. The pellets were resuspended and dissolved in buffer A containing $150 \mathrm{mM} \mathrm{NH}_{4} \mathrm{Cl}$, $50 \mathrm{mM}$ Tris $-\mathrm{HCl}\left(\mathrm{pH} 7.5\right.$ at $20^{\circ} \mathrm{C}$ ), $50 \mathrm{mM} \mathrm{MgCl}_{2}, 2 \mathrm{mM} \mathrm{Na}_{2}$ EDTA and $1 \mathrm{mM}$ dithiothreitol. The stirred ribosomes were precipitated by the addition of powdered ammonium sulfate to a final concentration of $3 \mathrm{M}$. The pellets were stored at $4^{\circ} \mathrm{C}$.

The purification procedure of protein S6 (TS9 according to the original nomenclature; Sedelnikova et al., 1987) has been published elsewhere (Agalarov and Eliseikina, 1989). Briefly, core particles obtained by the treatment of $30 \mathrm{~S}$ subunits with $3.5 \mathrm{M} \mathrm{LiCl}$ were subjected to $6 \mathrm{M} \mathrm{LiCl}$ to extract so-called core proteins. The solution containing these proteins was dialyzed against buffer B containing $50 \mathrm{mM}$ Tris $-\mathrm{HCl}(\mathrm{pH} 7.5$ at $20^{\circ} \mathrm{C}$ ), $1 \mathrm{mM}$ dithiothreitol and $0.02 \%(\mathrm{w} / \mathrm{v}) \mathrm{NaN}_{3}$. The dialyzed solution was loaded onto a $25-30 \mathrm{ml}$ column of CM-Sepharose CL-6B. As S6 is only slightly acidic it did not bind to this column material, in contrast to most other ribosomal proteins. The protein eluted in the unbound fraction with $85-90 \%$ purity. Further purification was obtained by ion exchange chromatography on a DEAE-Toyopearl $650 \mathrm{~S}$ column $(1.5 \mathrm{ml})$. When buffer $\mathrm{B}$ was used the protein did not bind to this column; it eluted with a purity of $95-98 \%$. When buffer $\mathrm{C}$ containing $20 \mathrm{mM}$ Tris $-\mathrm{HCl}\left(\mathrm{pH} 9.0\right.$ at $\left.20^{\circ} \mathrm{C}\right)$ was used with the same column, the protein was weakly retarded and was eluted with $40 \mathrm{ml}$ of a linear gradient from 0 to $100 \mathrm{mM} \mathrm{NaCl}$ in the same buffer. The purity of the S6 thus obtained was at least $98 \%$.

\section{Preparation of peptides for sequence analysis}

Digestions of the intact protein with trypsin [treated with 1-ptosylamino-2-phenylethylchloromethyl ketone (Worthington)] or endoproteinase Glu-C (Miles) were carried out in $0.2 \mathrm{M} \mathrm{N}$-ethylmorpholinum

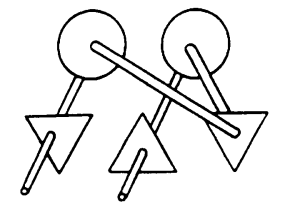

A

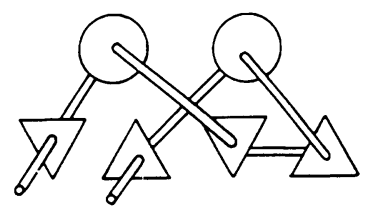

C

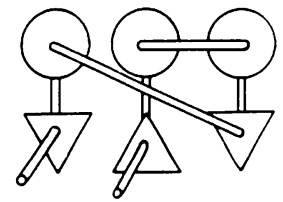

$B$

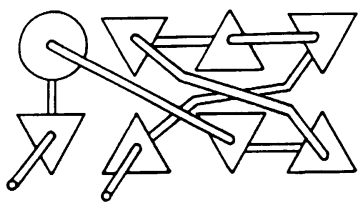

D

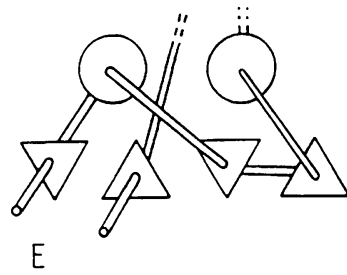

Fig. 5. Folding schemes of some related ribosomal and nucleic acid binding proteins: (A) L30; (B) C-terminal domain of L7/L12; (C) S6, U1A and E2; (D) C-terminal domain of L6; (E) palm domain of the Klenow fragment and p 66 of HIV-1 reverse transcriptase. Folds $(B-E)$ can be obtained by the insertion of secondary structure elements between the first helix and the second strand in (A). The ribosomal proteins S17 and S5 do not fit into this scheme.

acetate (pH 8.0) for $24 \mathrm{~h}$ at $37^{\circ} \mathrm{C}$ at a substrate:enzyme ratio of $30: 50$ Digestions with endoproteinase Lys-C (Boehringer) were performed in 0.2 $\mathrm{M}$ Tris $-\mathrm{HCl}(\mathrm{pH} 8.6)$ for $20 \mathrm{~h}$ at $37^{\circ} \mathrm{C}$ at a substrate:enzyme ratio of 1000:1. Cleavage by BrCN (Villa et al., 1989) was performed using $\sim 100$ $\mu \mathrm{g}$ of intact protein in $200 \mu \mathrm{l} 6 \mathrm{M}$ guanidinium chloride and $0.2 \mathrm{M} \mathrm{HCl}$ containing $6 \mathrm{mg} \mathrm{BrCN}$. Prior to high-performance liquid chromatography, $\mathrm{BrCN}$ was removed by passing a stream of nitrogen over the surface of the solution. Subdigestions on BrCN and endoproteinase Lys-C-generated peptides were carried out with endoproteinase Glu-C in $100 \mu \mathrm{l} 0.2 \mathrm{M}$ Tris $-\mathrm{HCl}(\mathrm{pH} 8.6)$ and with endoproteinase Asp- $\mathrm{N}$ (Boehringer) in 100 $\mu \mathrm{l} 0.2 \mathrm{M}$ ammonium carbonate $\left(\mathrm{pH} 8.5\right.$ ) for $4-20 \mathrm{~h}$ at $37^{\circ} \mathrm{C}$ using $0.03-0.20 \mu \mathrm{g}$ enzyme.

Peptides were usually separated on a Beckman Ultrasphere ODS-column $(4 \times 250 \mathrm{~mm})$ with 1 -h gradients of $0-80 \%(\mathrm{v} / \mathrm{v})$ acetonitrile in $0.1 \%$ $(\mathrm{v} / \mathrm{v})$ trifluoroacetic acid at a rate of $1.0 \mathrm{ml} / \mathrm{min}$. Rechromatography of impure peptides was performed under the same conditions, but with $0.1 \%$ (w/v) ammonium acetate ( $\mathrm{pH} 6.5$ ) instead of trifluoroacetic acid. In some cases, peptide separations were also done on a Merck Lichrosphere 100 $\mathrm{RP} 18 \mathrm{e}$ column $(4 \times 100 \mathrm{~mm})$. When large peptides were expected (e.g. with $\mathrm{BrCN}$ digestion), a Vydac protein $\mathrm{C} 4$ column $(4 \times 250 \mathrm{~mm})$ was used.

All sequence determinations were performed on an Applied Biosystems Model 475A pulse liquid protein sequencer, on-line equipped with a Model $120 \mathrm{~A}$ pth amino acid analyzer. The molecular mass of the C-terminal $\mathrm{BrCN}$ generated peptide was determined with a BioIon plasma desorption plasma mass spectrometer.

\section{Crystallization}

The procedure used for crystallization was as described by Sedelnikova $e t$ al. (1991). The hanging drop technique was used with $10 \mu \mathrm{l}$ drops of the protein solution equilibrated against $500 \mu \mathrm{l}$ of a precipitant solution. Drops containing $8-15 \mathrm{mg}$ protein $/ \mathrm{ml}, 0.05 \mathrm{M}$ Tris $-\mathrm{HCl}(\mathrm{pH} 7.5)$ and $0.1-0.2 \mathrm{M} \mathrm{KF}$ were equilibrated against $25 \%$ (v/v) methanepentanediol in $0.4 \mathrm{M} \mathrm{NaCl}$. Crystals shaped like rhombic prisms, with dimensions up to $0.4 \times 0.4 \times 0.2 \mathrm{~mm}$, were obtained within $40 \mathrm{~h}$ at room temperature.

Data collection and solution structure

$\mathrm{X}$-ray diffraction data were collected on a Siemens area detector equipped with a three-circle goniostat mounted on a Rigaku RU200BEH rotating 
A

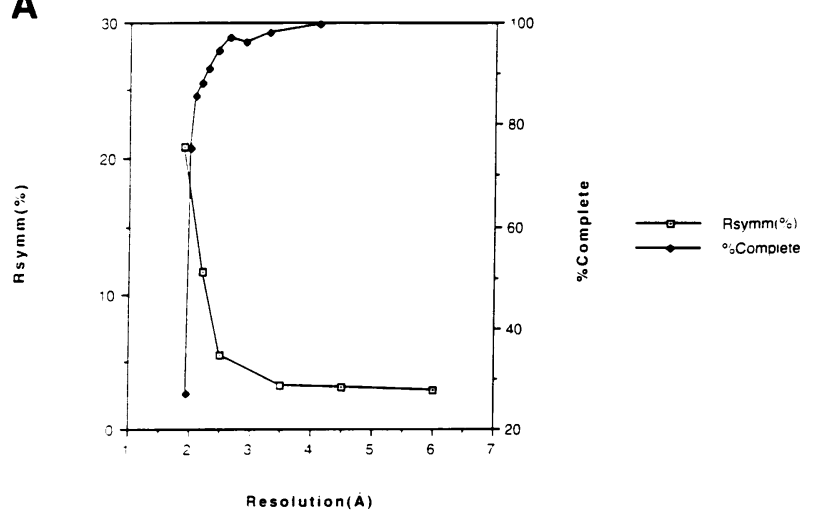

B

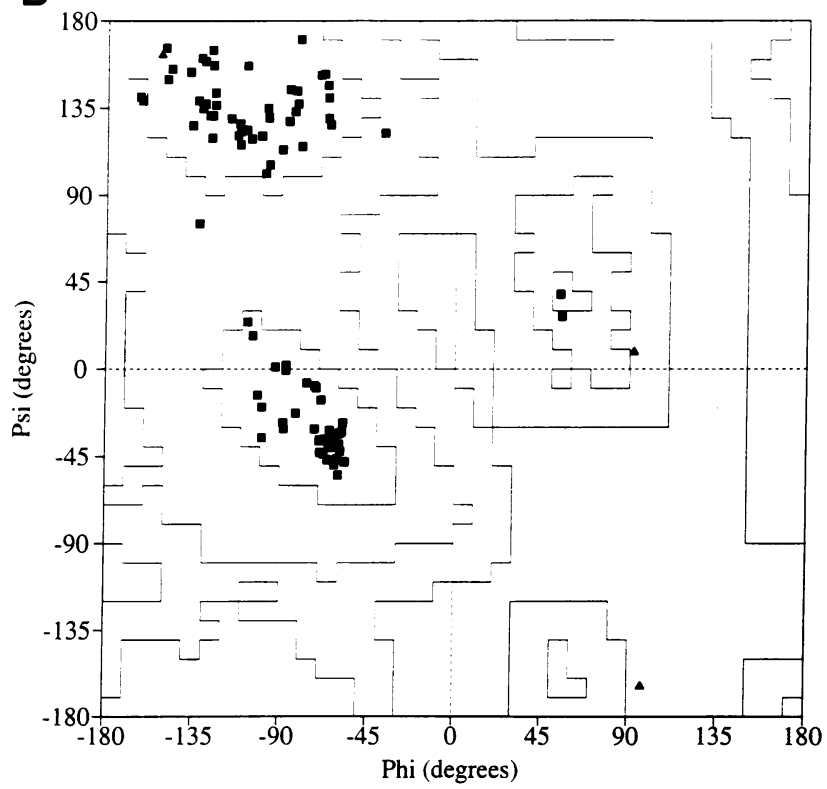

Fig. 6. (A) Completeness and $R_{\mathrm{s}}$ in resolution shells as a function of resolution for the native data set. $R_{\mathrm{s}}=\Sigma \Sigma|\mathrm{I}-<\mathrm{I}>| /|<\mathrm{I}>|$. One crystal was used and 7529 independent reflections $(92 \%$ at $2.0 \AA$ ) were obtained. (B) Ramachandran plot of the S6 structure. The allowed regions are shown in the figure. Glycines are marked as triangles. The plot is produced by the program PROCHECK (Laskowski et al., 1993).

anode. Reflexions were collected at $2 \theta=20^{\circ}$ and a frame width of $0.25^{\circ}$. The space group is C222 with $a=106.81, b=52.72$ and $c=41.12$ $\AA$, the resolution limit being $1.95 \AA$ A. Data processing was performed by XDS (Kabsch, 1988a,b). $R_{\mathrm{s}}$ and completeness as a function of resolution are summarized in Figure 6A. Phasing was performed by the MIR method using three similar mercury derivatives (Table I). The MIR phasing was useful to $2.1 \AA$. All calculations were performed by CCP4 (1979), the program MLPHARE (Otwinowski, 1991) being used for heavy atom refinement and phase calculation. Phase improvement by solvent flattening, histogram matching and adaptation of Sayre's equation to phase invariants was adapted by the program SQUASH (Zhang, 1993). MIR statistics are summarized in Table I. The enantiomorph ambiguity was resolved by incorporating anomalous differences from derivative (a) (see Table I). The enantiomorphs could also be clearly distinguished by the pitch of the $\alpha$ helices.

The structure was built with the program O (Jones et al., 1991). The entire sequence, except the C-terminal residues $97-101$, could be built into the electron density map. Refinement was performed by XPLOR (Brünger, 1992). After initial simulated annealing and subsequent steps of conventional refinement and manual intervention using an Evans and Sutherland graphical workstation, a final model with a crystallographic $R$-factor of $18.3 \%$ [ $(\mathrm{F}>1$ $\sigma, 8.00-1.95 \AA$ ) and r.m.s. bond length deviations of $0.017 \AA$, bond angle r.m.s. of $3.2 \AA$, dihedral angle r.m.s. of $24.8^{\circ}$ and improper dihedral angle r.m.s. of $1.85^{\circ}$ ] was obtained. Forty molecules of water have been inserted by inspection of difference electron density maps. The Ramachandran plot is shown in Figure 5B.

\section{Acknowledgements}

We are grateful to R.Karssies, SON Protein Sequencer Facility, Leiden and Chatarina Mattson, the BM-unit, Chemical Center, University of Lund, for expert technical assistance with the sequencing and mass spectrometric analysis, respectively. We thank the Swedish Royal Academy of Science (KVA), the Swedish Natural Science Research Council (NFR) and the Swedish Institute for funding.

\section{References}

Adman,E.T., Sieker,L.C. and Jensen,L.H. (1973) J. Biol. Chem., 248, 3987-3996.

Agalarov,S.Ch. and Eliseikina,I.A. (1989) Biopolimery i Kletka (USSR), 5, 77-79.

Brünger,A.T. (1992) X-PLOR, Version 3.0. Yale University, CT.

Capel,M.S.et al. (1987) Science, 238, 1403-1406.
Table I. Figure of merit after joint refinement by MLPHARE (Otwinowski, 1991): 0.71 (centric reflections), 0.50 (acentric reflections)

\begin{tabular}{llll}
\hline Measurement & \multicolumn{2}{l}{ Derivatives } & \\
\cline { 2 - 4 } & EtHgCl (a) & EtHgCl (b) & PCMB (c) \\
\hline $\mathrm{d} / \AA$ & 2.0 & 3.3 & 3.3 \\
No. of observations & 31290 & 10699 & 9837 \\
No. of unique & & & \\
Reflections & 7659 & 1783 & 1838 \\
Completeness (\%) & 94 & 90 & 93 \\
$R_{\mathrm{S}}(\%)^{\mathrm{a}}$ & 9.2 & 5.1 & 5.1 \\
No. of sites & 3 & 3 & 2 \\
Phasing power & 1.7 & 2.7 & 1.2 \\
$R_{\text {cullis }}{ }^{\mathrm{b}}$ & 0.67 & 0.45 & 0.76 \\
\hline
\end{tabular}

Anomalous differences were incorporated in the refinement for derivative (a). Derivatives (a) and (b) were prepared by soaking the crystals in saturated solutions $(<10 \mathrm{mM})$ of $\mathrm{EtHgCl}$ and precipitant for 72 (a) and 40 (b) h. Derivative (c) was prepared by soaking crystals in $1.0 \mathrm{mM}$ PCMB and precipitant for $40 \mathrm{~h}$.

${ }^{\mathrm{a}} R_{\mathrm{s}}=\Sigma \Sigma|\mathrm{I}-<\mathrm{I}>| /|<\mathrm{I}>|$.

b Phasing power $=$ r.m.s. $\left\langle F_{\mathrm{H}}\right\rangle|E\rangle$, where $\left\langle F_{\mathrm{H}}\right\rangle=$ heavy atom structure factor amplitude and $E=$ residual lack of closure.

${ }^{c} R_{\text {cullis }}=\Sigma|| F_{\mathrm{PH}} \pm F_{\mathrm{P}}\left|-F_{\mathrm{H}(\text { calc) }}\right| / \Sigma\left|F_{\mathrm{PH}}-F_{\mathrm{P}}\right|$ for centric reflections.

CCP4 (1979) The SERC (UK) Collaborative Computing Project No. 4. Daresbury Laboratory, Warrington, UK.

Dumas,C. et al. (1992) EMBO J., 11, 3203-3208.

Eriksson,P.O. and Sahlman,L. (1993) J. Biomol. NMR, 3, 613-626.

Gogia,Z.V., Yusupov,M.M. and Spirina,T.N. (1986) Mol. Biol. (USSR), 20, 519-526.

Golden,B.L., Ramakrishnan,V. and White,S.W. (1993) EMBO J., 12, 4901-4908.

Gonaux,J.E., Stevens,R.C. and Lipscomb,W.N. (1990) Biochemistry, 29, $7702-7715$.

Gribskov,M. and Burgess,R.R. (1986) Nucleic Acids Res., 14, 6745-6763.

Gutell,R.R (1993) Curr. Opin. Struct. Biol., 3, 313-322.

Hegde,R.S., Grossman,S.R., Laimins,L.A. and Sigler,P.B. (1992) Nature, 359, 505-512. 


\section{M.Lindahl et al.}

Held,W.A., Ballou,B., Mizushima,S. and Nomura,M. (1974) J. Biol. Chem., 249, 3103-3111.

Hitz,H., Schäfer,D. and Wittmann-Liebold,B. (1975) FEBS Lett., 56, $259 \div 262$.

Hoffman,D.W., Query,C.C., Golden,B.L., White,S.W. and Keene,J.D. (1991) Proc. Natl Acad. Sci. USA, 88, 2495-2499.

Hoffman,D.W., Davies,C., Gerchman,S.E., Kycia,J.H., Porter,S.J., White,S.W. and Ramakrishnan,V. (1994) EMBO J., 13, 205-212.

Jessen,T.-H., Oubridge,C., Teo,C.H., Pritchard,C. and Nagai,K. (1991) EMBO J., 10, 3447-3456.

Jones, T.A., Zou,J.-Y., Cowan,S.W. and Kjeldgaard,M. (1991) Acta Cryst., A47, $110-119$.

Jue,R.A., Woodbury,N.W. and Doolittle,R.F. (1980) J. Mol. Evol., 15, 129-148.

Kabsch,W. (1988a) J. Appl. Cryst., 21, 916-924.

Kabsch,W. (1988b) J. Appl. Cryst., 21, 67-71.

Kahan,L., Winkelmann,D.A. and Lake,J.A. (1981) J. Mol. Biol., 145, 193-214.

Kaltschmidt,E. and Wittman,H.G (1970) Proc. Natl Acad. Sci. USA, 67, $1276-1282$

Kohlstaedt,L.A., Wang,J., Friedman,J.M., Rice,P.A. and Steitz,T.A. (1992) Science, 256, 1783-1790.

Laskowski,R.A., MacArthur,M.W., Moss,D.S. and Thornton,J.M. (1993) J. Appl. Cryst., 26, 283-291.

Leijonmarck,M., Eriksson,S. and Liljas,A. (1980) Nature, 286, 824-826.

Leijonmarck,M., Appelt,K., Badger,J., Liljas,A., Wilson,K.S. and White,S.W. (1988) Proteins, 3, 243-251.

Mattaj,I.W. (1989) Cell, 57, 1-3.

Nagai,K., Oubridge,C., Jessen,T.H., Li,J. and Evans,P.R. (1990) Nature, $348,515-520$.

Ollis,D.L., Kline,C. and Steitz,T.A. (1985) Nature, 313, 762-766.

Orengo,C.A. and Thornton,J.M. (1993) Structure, 2, 105-120.

Otwinowski,Z. (1991) In Wolf,W., Evans,P.R. and Leslie,A.G.W. (eds), Isomorphous Replacement and Anomalous Scattering. SERC, Warrington, UK, pp. 80-86.

Pastore,A., Saudek,V., Ramponi,G. and Williams,R.J.P. (1992) J. Mol. Biol., 224, 427-440.

Prakash,V. and Aune,K.C. (1978) Arch. Biochem. Biophys., 187, 399-405.

Ramakrishnan,V. and White,S.W. (1992) Nature, 358, 768-771.

Schnier,J., Kitakawa,M. and Isono,K. (1986) Mol. Gen. Genet., 204, $126-132$.

Sedelnikova,S.E., Agaralov,S.Ch., Garber,M.B. and Yusopov,M.M. (1987) FEBS Lett., 220, 227-230.

Sedelnikova,S.E., Agalarov,S.Ch., Eliseikina,I.A., Fomenkova,N.P. Nikonov,S.V., Garber,M.B., Svensson,L.A. and Liljas,A. (1991) J. Mol. Biol., 220, 549-550.

Sousa,R., Chung,Y.J., Rose,J.P. and Wang,B.-C. (1993) Nature, 364, 593-599.

Stöffler,G. and Stöffler-Meilicke,M. (1984) Annu. Rev. Biophys. Biophys. Chem., 13, 303-330.

Villa,S., DeFazio,G. and Canosi,U. (1993) Anal. Biochem., 77, 161-164.

Wilson,K.S, Appelt,K., Badger,J., Tanaka,I. and White,S.W. (1986) J. Mol. Biol., 83, 7251-7255.

Wittman,H.G. (1982) Annu. Rev. Biochem., 51, 155-183.

Wittman-Liebold,B., Ashman,K. and Dzionara,M. (1984) Mol. Gen. Genet. 196, $439-448$.

Zhang,K.Y.J. (1993) Acta Cryst., D1, 213-222.

Received on October 11, 1993; revised on December 8, 1993 